Article

\title{
Modelling Nitrogen Losses from Sheep Grazing Systems with Different Spatial Distributions of Excreta
}

\author{
Matthew J. Bell *, Brendan R. Cullen, Ian R. Johnson and Richard J. Eckard \\ Melbourne School of Land and Environment, University of Melbourne, Vic. 3010, Australia; \\ E-Mails: bcullen@unimelb.edu.au (B.R.C.); ian@imj.com.au (I.R.J.); \\ rjeckard@unimelb.edu.au (R.J.E.) \\ * Author to whom correspondence should be addressed; E-Mail: Matt.Bell@unimelb.edu.au; \\ Tel.: +61-390-353974.
}

Received: 28 June 2012; in revised form: 7 September 2012 / Accepted: 10 September 2012 / Published: 25 September 2012

\begin{abstract}
The aim of this study was to assess the effect that the randomised versus even distribution of excreta (dung and urine) may have on modelling nitrogen $(\mathrm{N})$ losses by leaching, volatilisation and denitrification from a grazing system. A range of stock densities (from 200 to 2000 sheep/ha, equivalent to an annual stocking rate of 3 to 33 dry sheep equivalent (DSE)/ha respectively) were simulated to represent an increasing application of $\mathrm{N}$ excreta to a grazed 1 hectare area either distributed randomly or uniformly. This study found that the proportion of annual $\mathrm{N}$ inputs lost by denitrification were significantly lower and leaching $\mathrm{N}$ losses were higher at high stocking densities compared to if excreta was distributed uniformly. The results of this study indicate that $\mathrm{N}$ losses from a sheep grazing system could be adequately modelled assuming uniform distribution of excreta at stocking densities up to 1200 sheep/ha (equivalent to an annual stocking rate of $20 \mathrm{DSE} / \mathrm{ha}$ ). But at higher stock densities, when $\mathrm{N}$ loads are high, the spatial distribution of excreta is important and models need to explicitly deal with the distribution of dung and urine $\mathrm{N}$ returns.
\end{abstract}

Keywords: distribution; excreta; grazing system; modelling; nitrogen losses 


\section{Introduction}

Nutrients are lost from pasture systems largely through the actions of the grazing animal. Nitrogen $(\mathrm{N})$ losses from grazing systems through leaching, denitrification, volatilisation, and runoff are a potential source of ground water nitrate pollution or nitrous oxide $\left(\mathrm{N}_{2} \mathrm{O}\right)$ emissions to the atmosphere [1]. The $\mathrm{N}$ inputs to the grazing system, rainfall and the soil's $\mathrm{pH}$, hydraulic conductivity, water-filled pore space and temperature to a lesser extent, have been identified as key factors affecting soil $\mathrm{N}$ losses [1]. A previous study on dairy pastures at Ellinbank Research Farm in south-eastern Victoria (the site but not the soil modelled in this study) found that in grazing systems, where no synthetic fertiliser was used, the total losses of $\mathrm{N}$ by leaching, denitrification, volatilization were about $22 \%$ of the total $\mathrm{N}$ inputs [2].

Due to the distribution of nutrients in excreta being concentrated in dung and urine patches, there is potential for the quantities of nutrients supplied to be greater than the immediate requirements of the soil-plant system in these areas. This is exacerbated by excreta being naturally clustered together and overlapping in a given area, influenced by the density of livestock $[3,4]$. An increase in surplus $\mathrm{N}$ in a grazing system typically aligns with an increase in total $\mathrm{N}$ losses [2], particularly nitrate leaching [5].

The grazing area covered by excreta depends on the amount deposited, which is influenced by the number of animals, the quantity produced per animal and its concentration. The concentration of $\mathrm{N}$ in dung has been found to be less variable than urine $\mathrm{N}$ content, whereby the $\mathrm{N}$ content of urine appears to increase as dietary $\mathrm{N}$ increases beyond animal requirements [6]. Even though the area of an individual dung and urine patch is difficult to estimate, it is reasonable to assume in sheep that a dung and urine patch can be produced about 20 times per day with an approximate area of $0.025 \mathrm{~m}^{2}$ [3]. In comparison, cattle defecate about 10 times per day with an average patch area of about 0.05 and $0.2 \mathrm{~m}^{2}$ for dung and urine respectively [6]. The grazing area affected by excreta is not only a function of the type of livestock being carried by the pasture but also their stocking density. Nutrient returns as excreta to the paddock play a vital role in the whole-system nutrient dynamics, including plant growth, volatilisation, leaching and denitrification.

EcoMod [7] is a process-based biophysical pasture simulation model that includes pasture growth and utilisation by grazing animals, animal metabolism and growth (sheep and cattle), water and nutrient dynamics, and options for pasture management, irrigation and fertiliser application. It includes full carbon and nitrogen dynamics of the system, and their interactions. The model has been used to investigate the growth of different pasture species [8], as well as assessing the impact of climate variability [9], drought [10], business risk [11], and climate change [12,13]. The spatial and temporal variability in the $\mathrm{N}$ balance can be modelled on a daily time-step. EcoMod has been previously used to simulate $\mathrm{N}$ losses at a range of sites with different climates and soil types $[10,14,15]$. Process-oriented models are important when apportioning $\mathrm{N}$ losses from soils under different land use $[15,16]$. The single heterogeneous paddock (SHP) approach within EcoMod can help model the processes within the whole farm system that have a direct or indirect relationship to the concentration of $\mathrm{N}$ in excreta $[14,15]$. The SHP function within the model allows comparisons to be made between different allocation methods of excreta, which is not possible with other grazing system models. The need to study the impact of the non-uniform distribution of $\mathrm{N}$ excreta on not only leaching losses, but also volatilisation and denitrification losses under a managed grazing system has been identified [14]. 
Therefore, this study aimed to use the same model as other studies $[14,17]$ when simulating $\mathrm{N}$ loss from grazing systems, but further investigate the importance of dung and urine being randomly or evenly distributed to pasture. In comparison to a previous study using this model [17], this study looks to determine at what level of stock the spatial distribution of excreta becomes important.

The objective of this study was to (1) investigate the effect of random versus uniform distribution of excreta in a model on the predicted amount of $\mathrm{N}$ that is lost from a sheep grazing system by leaching, volatilisation and denitrification and (2) determine what level of stock is important to account for the spatial distribution of excreta in a model and (3) suggest developments to models that could better describe $\mathrm{N}$ losses from the grazing system.

\section{Material and Methods}

\subsection{Pasture Model and Site Simulated}

The single heterogeneous paddock (SHP) option within the dynamic biophysical model EcoMod [7,18] was used to allocate excreta (dung and urine together) to a grazed 1 ha area. For a full description of the model see [18]. The SHP approach allows a paddock's soil nutrients, pasture production and species composition to be simulated independently within a defined proportion of the grazed area on a daily time-step. Options are available with regard to how nutrients are returned to the pasture i.e., to a defined area with a chance of repeat deposits or spread evenly to the whole paddock. This model incorporates daily climate data, soil properties, pasture species, livestock and management to describe the whole farm system. The climate data inputs include minimum and maximum temperature $\left({ }^{\circ} \mathrm{C}\right)$, rainfall $(\mathrm{mm})$, solar radiation $\left(\mathrm{MJ} / \mathrm{m}^{2}\right)$, vapour pressure $(\mathrm{kPa})$ and minimum and maximum relative humidity (\%). The climate data were obtained from the SILO database [19].

Simulations were based on climate data from the years 1901 to 2000 for the Ellinbank Research Farm in south-eastern Victoria $\left(-38.25^{\circ} \mathrm{N}, 145.93^{\circ} \mathrm{E}\right)$. Ellinbank has a temperate climate (average daily minimum and maximum temperatures of 8.6 and $18.4{ }^{\circ} \mathrm{C}$ respectively) with a relatively high mean annual rainfall of $1054 \mathrm{~mm}$ during the study period. The soil type was a well-drained, basalt-derived, Red Mesotrophic Haplic Ferrosol [20]. The pasture system was a dryland (i.e., rainfed) perennial ryegrass (Lolium perenne L.) and white clover legume (Trifolium repens L. 1753) sward, which was grazed for a period of one day every 60 days (6 or 7 grazings per year) by $45 \mathrm{~kg}$ wethers, which were assumed to maintain their body weight. The model has previously been assessed to predict pasture growth rate at Ellinbank and has been found to give good agreement $[8,18]$.

The animal module describes the animal's energy requirements for maintenance (defined as $0.52 \times$ body weight ${ }^{\wedge .75} \mathrm{MJ} \mathrm{d}^{-1}$ ), feeding activity and body weight change (see [7], for details). The model assumes that the animal will try to eat enough food to meet its ME requirement, with ME intake constrained by the ME content of available feed and a constraint on the animal's DM intake depending on its digestibility $(1.8 \mathrm{~kg} / \mathrm{d}$ at $80 \%$ dry matter digestibility). The sheep grazed the same paddock every 60 days to allow the pasture biomass time to recover from grazing and so that allocation of excreta was compared on the same days. Growth of each pasture species in the model is described by the plant's photosynthesis and respiration response. In the model it was assumed that the optimum $\mathrm{N}$ content for photosynthesis was 4 and $4.5 \%$ for perennial ryegrass and white clover respectively. 
Of the $\mathrm{N}$ consumed by the animal, a fixed proportion of 0.15 of $\mathrm{N}$ intake was assumed to be retained by the animal and not defecated (as assumed by [14]). In the model, the proportion of $\mathrm{N}$ excreted in dung $\left(\varphi_{\mathrm{F}}\right)$ depends on the N-energy density $\left(\rho_{\mathrm{I}}\right)$ of feed intake $(\mathrm{kg} \mathrm{N} / \mathrm{MJ})$ and the proportion of $\mathrm{N}$ intake that is excreted $\left(\lambda_{\mathrm{N}}\right)$ :

$$
\varphi_{\mathrm{F}}=\beta+(\alpha-\beta) \exp \left(-\gamma \rho_{\mathrm{I}} \lambda_{\mathrm{N}}^{2}\right)
$$

where $\alpha$ and $\beta$ were assumed to be 45 and $13 \%$ for values of $\varphi_{\mathrm{F}}$ at very low and very high $\lambda_{\mathrm{N}}$ respectively, and $\gamma$ is an empirical coefficient, which was assumed to be $560 \mathrm{MJ} / \mathrm{kg} \mathrm{N}$.

No supplementary feed was fed to the sheep, which meant that the only true $\mathrm{N}$ input to the system was from fixation by legumes. Thus as stocking rates increased the pasture systems would become more $\mathrm{N}$ deficient. It was assumed that one animal would produce $0.5 \mathrm{~m}^{2}$ of excreta (20 deposits of $0.025 \mathrm{~m}^{2}$ including both dung and urine) each grazing day [3].

The model allows a minimum of $1 \%$ of the paddock to receive excreta and so a range of stocking densities from 200 to 2000 sheep/ha (increasing in 200 sheep/ha intervals) was used to allocate an increasing amount of excreta produced by the animals. Assuming that a $45 \mathrm{~kg}$ wether is 1 dry sheep equivalent (DSE; [21]), the range of stocking densities simulated would equate to a range in annual stocking rate of 3 to $33 \mathrm{DSE} / \mathrm{ha}$. The model simulated the allocation of excreta produced by the range of stock densities to the grazed area either: randomly [22] over 1 to $10 \%$ of the grazed area per day representing an increase in excreta applied to the pasture by increasing the stocking density from 200 to 2000 sheep/ha (in 200 sheep/ha intervals) or uniformly spread to the whole 1 ha grazed area. The random and uniform allocation of dung with urine was applied so comparisons could be made between modelled $\mathrm{N}$ allocation methods - even though dung and urine would typically be excreted separately by the grazing animal.

\subsection{Nitrogen Predictions}

Grazing system simulations were run for 100 years from 1901 to 2000 to allow for full expression of the nitrogen balance and its variability. A subset of 40 years from 1961 to 2000 was used for the analysis. The average annual $\mathrm{N}$ inputs $(\mathrm{kg} \mathrm{N} / \mathrm{ha})$ to the grazing system by excreta and fixation by legumes were predicted by the model.

The model apportions predicted $\mathrm{N}$ losses ( $\mathrm{kg} \mathrm{N} / \mathrm{ha}$ ) from the system by volatisation, denitrification and leaching in this order. Ammonia volatisation from urine is influenced by temperature and rainfall. Temperature had a linear effect on volatilisation $\left(0.20 \times \mathrm{kg}\right.$ urine $\mathrm{N} \times$ temperature $\left.{ }^{\circ} \mathrm{C} / 20\right)$ and rainfall greater than $5 \mathrm{~mm}$ stopped volatilisation. Nitrification and denitrification in the model are influenced by temperature, water filled pore space (WFPS) and soil carbon status, using the same generic response functions as for other soil processes. The model includes a mechanistic treatment of the rate of nitrification as a function of available soil ammonium $\left(\mathrm{NH}_{4}{ }^{+}\right)$and denitrification as a function of available soil nitrate $\left(\mathrm{NO}_{3}\right)$. As the soil moisture increases above wilting point oxygen diffusion in the soil is hindered and thus slows the rate of nitrification, but promotes denitrification, due to increasing anaerobicity, with a consequent release of both $\mathrm{N}_{2} \mathrm{O}$ and $\mathrm{N}_{2}$ [23]. Modelled $\mathrm{N}_{2} \mathrm{O}$ losses increase exponentially after 0.6 saturation of the WFPS, and decrease after saturation at 0.8 , with cessation of $\mathrm{N}_{2} \mathrm{O}$ loss at 0.95 saturation of the WFPS, with all products of denitrification being nitrogen gas $\left(\mathrm{N}_{2}\right)$ 
thereafter $[23,24]$. Nitrous oxide from nitrification was not predicted by the model, as nitrification was considered a minor source of $\mathrm{N}_{2} \mathrm{O}$ in pasture systems in terms of total $\mathrm{N}$ loss [1]. Temperature, WFPS and soil carbon status influenced the rate of denitrification, with an assumed maximum rate of denitrification of $0.25 \mathrm{mg} \mathrm{N} \mathrm{kg}^{-1}$ soil. Full details of the model structure are given in [7].

\subsection{Data Analysis}

The data were analysed using Genstat Version 12.1 [25]. The Mann-Whitney U-Test was used to evaluate any significant difference in total pasture intake ( $\mathrm{t} \mathrm{DM} / \mathrm{ha}$ ), $\mathrm{N}$ intake, total $\mathrm{N}$ inputs (excreta and legume fixation) to the system, amount of $\mathrm{N}$ fixed by legumes (all $\mathrm{kg} \mathrm{N} / \mathrm{ha}$ ), total $\mathrm{N}$ losses, and proportion of $\mathrm{N}$ inputs lost by leaching, volatilisation and denitrification for an increasing stocking density of 200 to 2000 sheep/ha with their excreta distributed uniformly or randomly to the grazed area. Significance was attributed at a value of $P<0.05$.

\section{Results}

\subsection{Pasture Intake}

There was a consistent decline in soil $\mathrm{N}$ content over time in all simulations (Figure 1).

Figure 1. Simulated total soil nitrogen $(\mathrm{N} ; \mathrm{t} / \mathrm{ha})$ content at the end of a calendar year for the site of Ellinbank between the years 1961 to 2000 when excreta from 200 sheep/ha (一) and 2000 sheep/ha (- -) was distributed uniformly $(\mathbf{a})$ or randomly $(\times)$ to a 1 hectare grazed area using the EcoMod model.

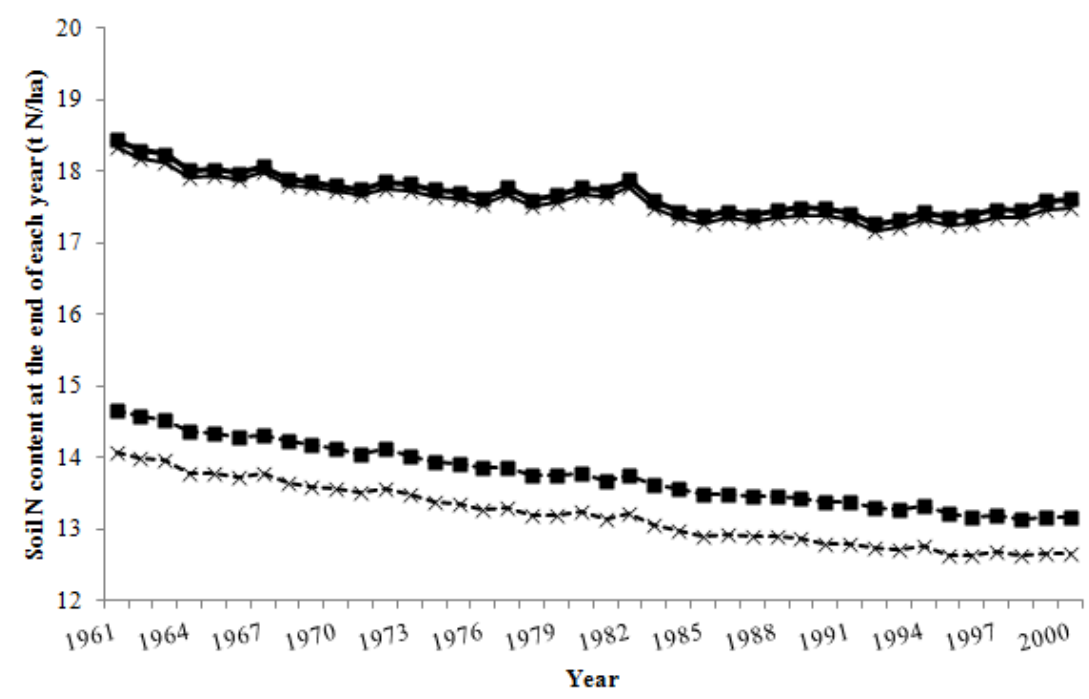

Figure 2 shows the average annual $\mathrm{N}$ in soil, plant matter, fixed by legumes and retained (removed) by the grazing animal, and losses by volatilisation, denitrification and leaching for each simulated pasture system. In the simulation in Figure 1 and in Figure 2, the grazing system with 2000 sheep/ha and a random distribution for excreta resulted in the lowest soil $\mathrm{N}$ content. 
Figure 2. Average annual grazing system nitrogen $(\mathrm{N} ; \mathrm{kg} / \mathrm{ha})$ in the soil, plant matter, fixed by legumes and removed by the grazing animal, and lost by volatilisation, denitrification and leaching when excreta from 200 to 2000 sheep/ha was distributed uniformly $(\mathrm{U})$ or randomly $(\mathrm{R})$ to a 1 hectare grazed area using the EcoMod model for a 40 year simulation run. Note the $\mathrm{x}$-axis starts at $13,000 \mathrm{~kg} \mathrm{~N} / \mathrm{ha}$.

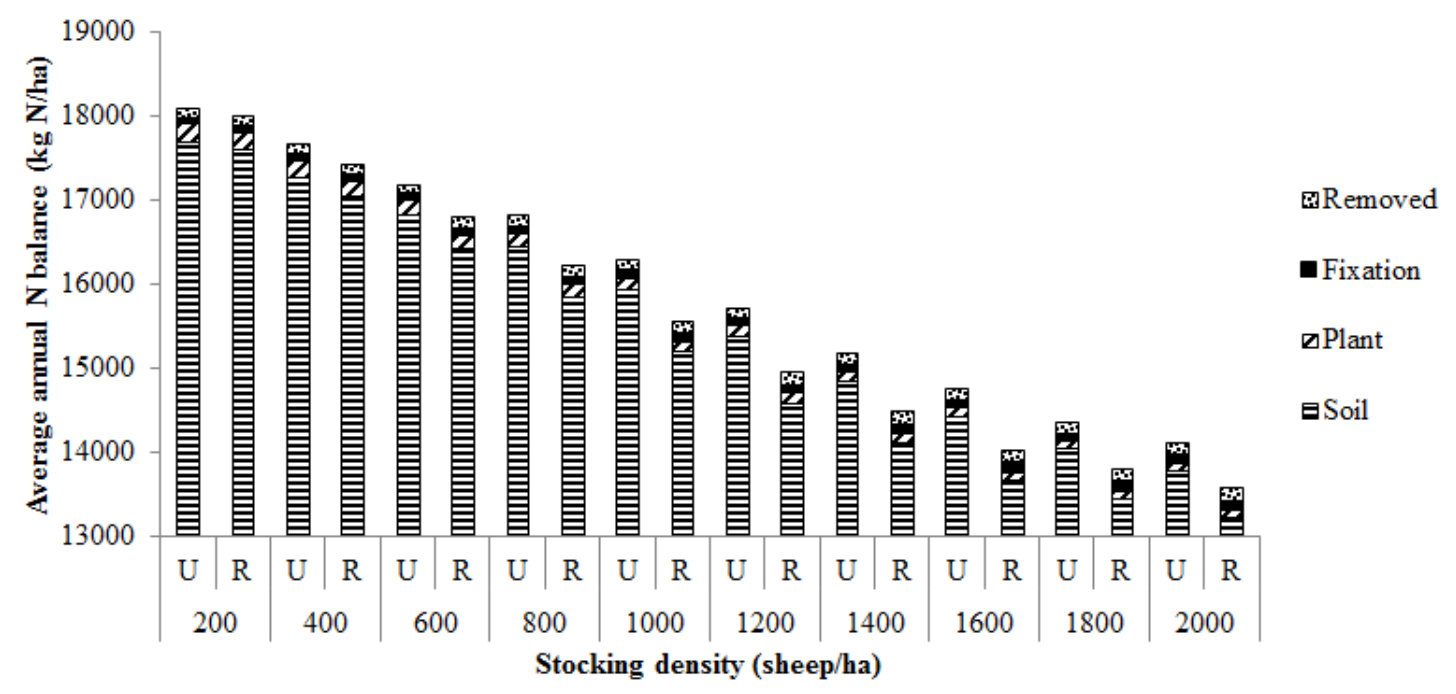

When excreta was distributed uniformly to the pasture at stocking densities of 1600 to 2000 sheep/ha the average pasture intake of the sheep was significantly greater than if excreta was distributed randomly $(P<0.05$; Table 1$)$. The concentration of $\mathrm{N}$ in the pasture ranged from $4.3 \%$ to $4.6 \%$ across the range of stocking densities applied. The $\mathrm{N}$ intake/ha of the sheep was also significantly greater at stock densities of 1200 to 2000 sheep/ha when excreta was distributed uniformly rather than randomly $(P<0.05)$.

Table 1. Predicted average pasture intake, nitrogen $(\mathrm{N})$ intake of sheep, $\mathrm{N}$ fixation by legumes and with $\mathrm{N}$ excreted by sheep which was distributed uniformly (U) and randomly (R) to a 1 hectare grazed area with a stocking density from 200 to 2000 sheep/ha.

\begin{tabular}{|c|c|c|c|c|c|c|c|c|c|c|c|}
\hline \multirow{4}{*}{$\frac{\text { Sheep/ha }}{200}$} & \multicolumn{3}{|c|}{ Pasture intake (t DM/ha) } & \multicolumn{3}{|c|}{$\mathrm{N}$ intake (kg N/ha) } & \multicolumn{3}{|c|}{$\mathrm{N}$ fixation (kg N/ha) } & \multicolumn{2}{|c|}{$\mathrm{N}$ excreta $+\mathrm{N}$ fixation } \\
\hline & $\mathrm{U}$ & $\mathrm{R}$ & & $\mathrm{U}$ & $\mathrm{R}$ & & $\mathrm{U}$ & $\mathrm{R}$ & & $\mathrm{U}$ & $\mathrm{R}$ \\
\hline & \multicolumn{2}{|c|}{ Mean (s.d.) } & \multirow[t]{2}{*}{$P$ value } & \multicolumn{2}{|c|}{ Mean (s.d.) } & \multirow[t]{2}{*}{ P value } & \multicolumn{2}{|c|}{ Mean (s.d.) } & \multirow[t]{2}{*}{$P$ value } & \multicolumn{2}{|c|}{ Mean (s.d.) } \\
\hline & $0.8(0.1)$ & $0.9(0.1)$ & & $40(3)$ & $40(3)$ & & $86(12)$ & $87(12)$ & & $121(12)$ & $121(12)$ \\
\hline 400 & $1.7(0.1)$ & $1.7(0.1)$ & & $78(5)$ & $77(5)$ & & $87(12)$ & $88(12)$ & & $153(13)$ & $153(13)$ \\
\hline 600 & $2.5(0.2)$ & $2.5(0.2)$ & & $114(8)$ & $112(7)$ & & $83(11)$ & $91(14)$ & $<0.05$ & $180(12)$ & $186(16)$ \\
\hline 800 & $3.3(0.3)$ & $3.3(0.3)$ & & $149(10)$ & $145(10)$ & & $87(18)$ & $97(31)$ & $<0.05$ & $214(20)$ & $221(34)$ \\
\hline 1000 & $4.1(0.3)$ & $4.0(0.3)$ & & $181(13)$ & $176(15)$ & & $90(21)$ & $99(19)$ & $<0.01$ & $244(25)$ & $249(26)$ \\
\hline 1200 & $4.8(0.4)$ & $4.7(0.5)$ & & $210(18)$ & $202(19)$ & $<0.05$ & $87(11)$ & $105(17)$ & $<0.001$ & $265(22)$ & $277(28)$ \\
\hline 1400 & $5.4(0.6)$ & $5.2(0.6)$ & & $235(24)$ & $224(24)$ & $<0.05$ & $89(11)$ & $114(25)$ & $<0.001$ & $289(27)$ & $304(40)$ \\
\hline 1600 & $5.8(0.7)$ & $5.4(0.7)$ & $<0.01$ & $252(29)$ & $233(28)$ & $<0.01$ & $90(10)$ & $116(19)$ & $<0.001$ & $305(32)$ & $314(39)$ \\
\hline 1800 & $6.1(0.7)$ & $5.6(0.7)$ & $<0.01$ & $264(31)$ & $242(31)$ & $<0.001$ & $94(12)$ & $118(21)$ & $<0.001$ & $319(35)$ & $324(43)$ \\
\hline 2000 & $6.4(0.8)$ & $5.8(0.7)$ & $<0.001$ & $274(33)$ & $248(31)$ & $<0.001$ & $96(12)$ & $120(22)$ & $<0.001$ & $329(38)$ & $330(44)$ \\
\hline
\end{tabular}




\subsection{Nitrogen Inputs and Losses from the Grazing System}

Whilst $\mathrm{N}$ intake was significantly greater at high stock densities when the excreta were distributed uniformly, the total $\mathrm{N}$ return of excreta plus $\mathrm{N}$ fixed by legumes to the pasture system were not significantly different between the simulated grazing systems for both methods of distributing excreta $(P>0.05$; Table 1). Even though the standard deviation in total $\mathrm{N}$ inputs (excreta + fixation) increased as stock density increased, the amount of $\mathrm{N}$ fixed by legumes meant there was no overall significant difference in these $\mathrm{N}$ inputs between the uniform and random distributions before accounting for $\mathrm{N}$ losses from the system. On its own, the amount of $\mathrm{N}$ fixed by legumes at $>600$ sheep /ha was significantly more when excreta was distributed randomly rather than uniformly $(P<0.05$; Table 1$)$.

Figure 3 shows that the average annual $\mathrm{N}$ leaching losses from the system ranged from $91 \pm 62$ to $67 \pm 29 \mathrm{~kg} \mathrm{~N} / \mathrm{ha}$ and $92 \pm 60$ to $95 \pm 37 \mathrm{~kg} \mathrm{~N} / \mathrm{ha}$ for low to high stocking densities and uniform and randomly distributed excreta respectively. Volatilisation $\mathrm{N}$ losses ranged from $3.1 \pm 0.7$ to $21 \pm$ $4.7 \mathrm{~kg} \mathrm{~N} / \mathrm{ha}$ and $3.1 \pm 0.7$ to $19 \pm 4.7 \mathrm{~kg} \mathrm{~N} /$ ha for low to high stocking densities and uniform and randomly distributed excreta respectively. Whereas, denitrification losses were $5.4 \pm 2.7$ to $4.8 \pm$ $1.2 \mathrm{~kg} \mathrm{~N} / \mathrm{ha}$ and $5.1 \pm 2.6$ to 4.0 to $0.7 \mathrm{~kg} \mathrm{~N} / \mathrm{ha}$ for low to high stocking densities and uniform and randomly distributed excreta respectively. On average, the $\mathrm{N} /$ ha lost by leaching remained at a similar level when excreta was distributed randomly to the grazed area but gradually reduced for the uniformly distributed excreta with increasing stock density. Volatilisation $\mathrm{N}$ losses increased with an increasing area of the grazing receiving excreta, and denitrification losses showed a similar pattern to leaching, however for both volatilisation and denitrification the losses were higher when excreta was distributed uniformly rather than randomly at higher stocking densities.

\subsection{Proportion of Total Nitrogen Inputs Lost from the Grazing System}

At the site simulated, the proportion of total $\mathrm{N}$ inputs (from excreta and $\mathrm{N}$ fixation by legumes) lost from the grazed area (Figure 4) declined as the stock density and pasture intakes increased (Table 1). Distributing excreta uniformly over the grazed area reduced the proportion of total $\mathrm{N}$ inputs lost $(P<0.05$ to $P<0.001$ for 1400 to 2000 sheep/ha) and in particular $\mathrm{N}$ lost by leaching $(P<0.01$ to $P<0.001$ for 1400 to 2000 sheep/ha). In some years, the $\mathrm{N}$ in the soil would start to build up in the soil and then be lost later in higher rainfall years (Figure 1). This resulted in the proportion of total $\mathrm{N}$ inputs in a year that were lost being more than one; hence for 200 sheep/ha the standard deviation was greater than one. 
Figure 3. Average annual nitrogen $(\mathrm{N} ; \mathrm{kg} / \mathrm{ha}$ ) lost by (a) leaching (b) volatilization and (c) denitrification when excreta from 200 to 2000 sheep/ha was distributed uniformly (a) or randomly ( $\square$ ) to the grazed area using the EcoMod model for a 40 year simulation run. Vertical bars indicate standard deviation for the 40 year model runs.
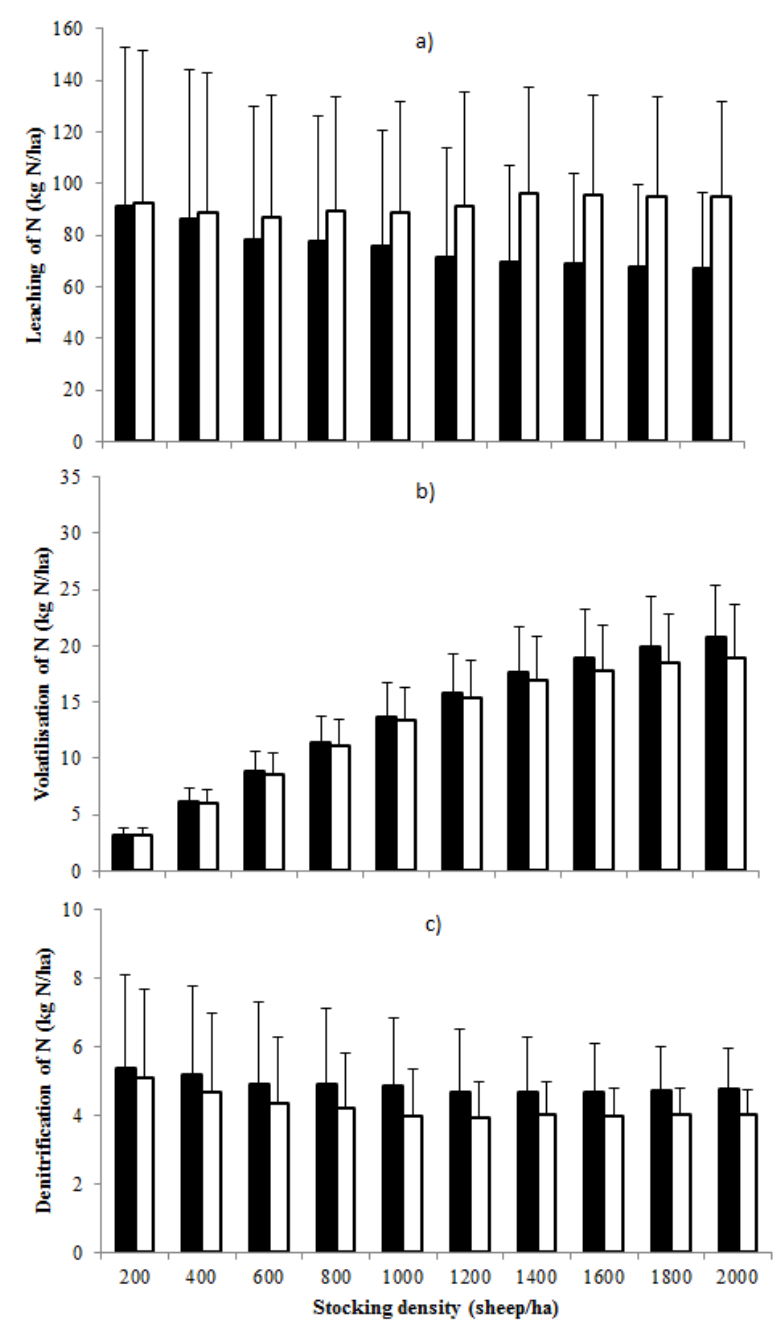

Figure 4 shows that the proportion of total $\mathrm{N}$ inputs lost by leaching averaged 0.75 at 200 sheep/ha to 0.21 and 0.29 at $2000 \mathrm{sheep} / \mathrm{ha}$ for uniform and random distributions of excreta respectively. In comparison, the proportion of $\mathrm{N}$ inputs lost by volatilisation ranged from 0.03 to 0.06 and 0.04 to 0.01 for denitrification losses across the range of stocking densities. The proportion of $\mathrm{N}$ inputs lost by volatilisation was not significantly different between uniformly and randomly distributed excreta across the range of stocking densities $(P>0.05)$. Even though the proportion of $\mathrm{N}$ inputs lost by denitrification each year was low, it was significantly greater at higher stocking densities when excreta was distributed uniformly rather randomly to the grazed area $(P<0.05$ to $P<0.01$ for 1200 to 2000 sheep/ha). 
Figure 4. Proportion of (a) total nitrogen $(\mathrm{N} ; \mathrm{kg} / \mathrm{ha}$ ) inputs that were lost and the proportion lost by (b) leaching (c) volatilisation or (d) denitrification when excreta from 200 to 2000 sheep/ha was distributed uniformly ( $\mathbf{a}$ ) or randomly ( $\square$ ) to a 1 hectare grazed area using the EcoMod model for a 40 year simulation run. Vertical bars indicate standard deviation for the 40 year model runs.
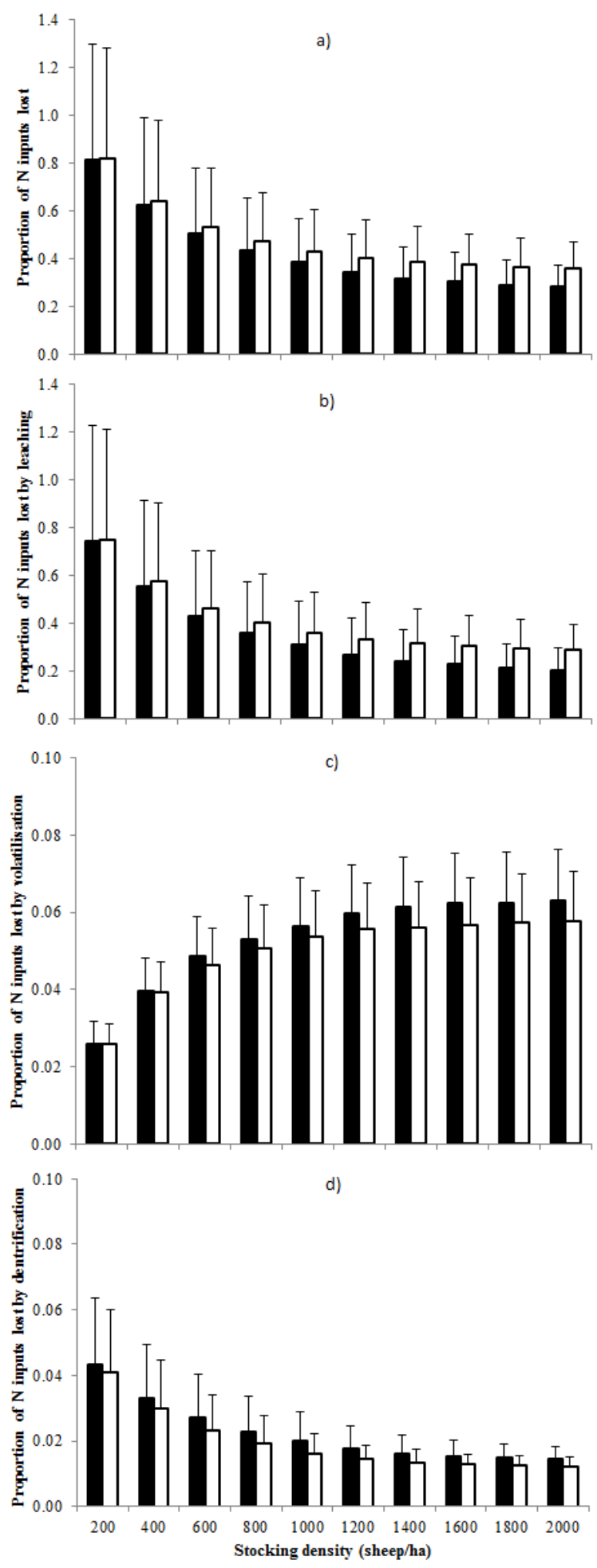


\section{Discussion}

The decline in soil and system $\mathrm{N}$ over time was directly a function of new $\mathrm{N}$ input to the system being limited to legume $\mathrm{N}_{2}$ fixation, coupled with $\mathrm{N}$ losses from the system over time; this was a function of the modelling assumptions.

Based on the modelling approach used in this study, the distribution of excreta influenced not only leached $\mathrm{N}$ losses (as was also found by [14]) but also denitrification $\mathrm{N}$ losses. The study by [14], modelled the sequential allocation of urine from cattle, in contrast to dung and urine being allocated in a more characteristic random distribution from sheep in the present study. There was no significant effect on $\mathrm{N}$ losses by volatilisation by the method of excreta allocation in this study, as volatilisation was modelled as a fixed proportion of urine $\mathrm{N}$ deposited and the effect of ambient temperature and rainfall on urine $\mathrm{N}$ rather than soil conditions. This may require further development in a more dynamic and mechanistic process in the model. A function of the model is that it estimates volatilisation $\mathrm{N}$ losses, then denitrification and lastly leaching losses. The available $\mathrm{N}$ to be leached is therefore influenced by this order of $\mathrm{N}$ losses, and may have contributed to the decline in the proportion of $\mathrm{N}$ lost by leaching and denitrification in this study with increasing stock density. However, as volatilisation was a fixed proportion, the relative changes in leaching and denitrification over simulated treatments would still be relevant.

The loss of $\mathrm{N}$ from a grazing system can vary considerable depending on the climate, soil, pasture species and grazing animal at a given location [15]. Under the conditions simulated, this study suggests that the uniform distribution of $\mathrm{N}$ to the whole grazed area and in an increasing amount (modelled by an increased stocking density) may promote better plant utilisation and growth, resulting in higher animal $\mathrm{N}$ intake and potentially less $\mathrm{N}$ leaching than if randomly allocated. Naturally, however, nitrogen excreted by grazing animals is distributed randomly in clusters and concentrated in small areas [3]. The random allocation and potential overlap of $\mathrm{N}$ returned can lead to a higher concentration of nutrients in a given area and increased risk of leaching, which was the main source of $\mathrm{N}$ loss from the grazing system in this study. The amounts of $\mathrm{N}$ leached were higher than you would expect from a grazing system at Ellinbank, which was due to the high densities of sheep simulated and more freely draining soil type simulated, than in the study by [2], resulting in large amounts of surplus $\mathrm{N}$ and nitrate leaching.

Even though $\mathrm{N}$ losses by denitrification were relatively small ( 0.01 to 0.04 of total $\mathrm{N}$ inputs), due to a free draining soil used in the simulation, randomly distributing excreta significantly reduced denitrification losses at higher stocking densities (1200 sheep/ha or more). However, this surplus N left over can then potentially be leached from the soil if it is not taken up by the pasture. Although denitrification can be a small component of the overall $\mathrm{N}$ dynamics, it can be a significant source of the greenhouse gas $\mathrm{N}_{2} \mathrm{O}$. The average amounts of $\mathrm{N}$ lost by denitrification across stocking densities in

this study for a random excretal distribution were slightly lower at 5.1 to $4.0 \mathrm{~kg} / \mathrm{ha}$ than field measurements taken at the same site over a 3 year period for a dairy grazing system [2], which averaged $6.7 \mathrm{~kg} / \mathrm{ha}$. This would be expected given the difference in soil types. The authors reported a similar average amount of $115 \mathrm{~kg} / \mathrm{ha}$ of $\mathrm{N}$ fixed by legumes each year as seen in this study (Table 1) and amount of $\mathrm{N}$ lost by volatilisation (averaging $18 \mathrm{~kg} \mathrm{~N} / \mathrm{ha}$ ) from the dairy system that would be comparable to levels produced at high stocking densities of sheep in this study (Figure 3). 
As discussed by [14], it is a weakness of pastoral simulation models to ignore that grazing ruminants return the nutrients in their excreta in patches within the grazed area rather than evenly. This study showed that assuming a homogenous distribution of excreta to the pasture would have been adequate to simulate annual $\mathrm{N}$ fluxes within the grazing system at lower $\mathrm{N}$ input levels or low stock densities (1200 or less sheep/ha or $20 \mathrm{DSE} / \mathrm{ha}$ ). However, for stocking rates of 20 or more DSE/ha where $\mathrm{N}$ excreta returns are high, inclusion of a distribution function that describes the clustering and overlap of $\mathrm{N}$ inputs in the model would describe the $\mathrm{N}$ losses from the system better (i.e., the SHP approach). This does add complexity to the model, but the distribution of excreta to pasture can significantly influence pasture growth and prediction of $\mathrm{N}$ losses from different sources within the system. A negative binomial distribution has been found to be the most suitable model to describe the distribution of excreta, as it incorporates overlap and clustering of deposits $[3,26]$. This approach includes a Poisson Index function that allows for a change in clustering with increased stocking density. A decrease in the Poisson Index with an increasing stocking density would allow more clustering and potential overlap of excreta than can be obtained by assuming that excreta is randomly distributed [3] as in this study.

\section{Conclusions}

This study modelled the $\mathrm{N}$ dynamics within a sheep grazing system using the single heterogeneous paddock (SHP) option in EcoMod that allows the simulation of dung and urine patch dynamics within a single paddock. Our analysis has considered the impact of the randomised nature of dung and urine $\mathrm{N}$ returns to a grazing system on leaching, volatilisation and denitrification $\mathrm{N}$ losses. Our analysis suggests that the impact on $\mathrm{N}$ losses from a grazing system by the spatial distribution of $\mathrm{N}$ inputs is more significant at high $\mathrm{N}$ input levels, which in this study was at 20 or more DSE/ha, where the $\mathrm{N}$ excreta returns and losses could be considered more characteristic of a dairy system. There are few models that can simulate $\mathrm{N}$ fluxes within a grazing system and allow different distribution methods to be simulated. Further developments of the model would allow the randomised excretal returns using approaches similar to the SHP to be used across a range of stocking densities and grazing systems.

\section{Acknowledgments}

This work was supported by funding from Dairy Australia, Meat and Livestock Australia and the Australian Government Department of Agriculture, Fisheries and Forestry under its Australia's Farming Future Climate Change Research Program.

\section{References and Note}

1. De Klein, C.A.M.; Eckard, R.J. Targeted technologies for nitrous oxide abatement from animal agriculture. Aust. J. Agr. Res. 2008, 48, 14-20.

2. Eckard, R.J.; Chapman, D.F.; White, R.E. Nitrogen balances in temperate perennial grass and clover dairy pastures in south-eastern Australia. Aust. J. Agr. Res. 2007, 58, 1167-1173.

3. Morton, J.D.; Baird, D.B. Spatial distribution of dung patches under sheep grazing. New Zeal. J. Agr. Res. 1990, 33, 285-294. 
4. Pleasants, A.B.; Shorten, P.R.; Wake, G.C. The distribution of urine deposited on a pasture from grazing animals. J. Agr. Sci. 2007, 145, 81-86.

5. Hanegraaf, M.C.; den Boer, D.J. Perspectives and limitations of the Dutch minerals accounting system (MINAS). Eur. J. Agron. 2003, 20, 25-31.

6. Haynes, R.J.; Williams, P.H. Nutrient cycling and soil fertility in the grazed pasture ecosystem. Adv. Agron. 1993, 49, 119-199.

7. Johnson, I.R. Biophysical Pasture Model Documentation: Model Documentation for Dairymod, Ecomod and the Sgs Pasture Model; IMJ Consultants: Fitzroy, Australia, 2008. Available online: http://www.imj.com.au (accessed on 1 July 2012).

8. Cullen, B.R.; Eckard, R.J.; Callow, M.N.; Johnson, I.R.; Chapman, D.F.; Rawnsley, R.P.; Garcia, S.C.; White, T.; Snow, V.O. Simulating pasture growth rates in Australian and New Zealand grazing systems. Aust. J. Agr. Res. 2008, 59, 761-768.

9. Chapman, D.F.; Cullen, B.R.; Johnson, I.R.; Beca, D. Interannual variation in pasture growth rate in Australian and New Zealand dairy regions and its consequences for system management. Anim. Prod. Sci. 2009, 49, 1071-1079.

10. Lodge, G.M.; Johnson, I.R. Agricultural drought analyses for temperate Australia using a biophysical pasture model. 1. Identifying and characterising drought periods. Aust. J. Agr. Res. 2008, 59, 1049-1060.

11. Chapman, D.F.; Kenny, S.N.; Beca, D.; Johnson, I.R. Pasture and crop options for non-irrigated dairy farms in southern Australia. 2. Inter-annual variation in forage supply, and business risk. Agr. Syst. 2008, 97, 126-138.

12. Cullen, B.R.; Johnson, I.R.; Eckard, R.J.; Lodge, G.M.; Walker, R.G.; Rawnsley, R.P.; McCaskill, M.R. Climate change effects on pasture systems in south-eastern Australia. Crop Pasture Sci. 2009, 60, 933-942.

13. Cullen, B.R.; Eckard, R.J.; Rawnsley, R.P. Resistance of pasture production to projected climate changes in south-eastern Australia. Crop Pasture Sci. 2012, 63, 77-86.

14. Snow, V.O.; Johnson, I.R.; Parsons, A.J. The single heterogeneous paddock approach to modelling the effects of urine patches on production and leaching in grazed pastures. Crop Pasture Sci. 2009, 60, 691-696.

15. Eckard, R.J.; Cullen, B.R. Impacts of future climate scenarios on $\mathrm{N}_{2} \mathrm{O}$ emissions from pasture-based dairy systems in SE Australia. Anim. Feed Sci. Technol. 2011, 166, 736-748.

16. Boeckx, P.; van Cleemput, $\mathrm{O}$. Estimates of $\mathrm{N}_{2} \mathrm{O}$ and $\mathrm{CH}_{4}$ fluxes from agricultural lands in various regions in Europe. Nutr. Cycl. Agroecosyst. 2001, 60, 35-47.

17. Bell, M.; Cullen, B.; Eckard, R. Effect on nitrogen losses from a sheep grazing system by the randomised distribution of excreta. In Proceedings of 2011 International Congress on Modelling and Simulation (MODSIM 2011), Perth, Australia, 12-16 December 2011.

18. Johnson, I.R.; Chapman, D.F.; Snow, V.O.; Eckard, R.J.; Parsons, A.J.; Lambert, M.G.; Cullen, B.R. DairyMod and EcoMod: Biophysical pastoral simulation models for Australia and New Zealand. Aust. J. Exp. Agric. 2008, 48, 621-631.

19. Jeffrey, S.J.; Carter, J.O.; Moodie, K.M.; Beswick, A.R. Using spatial interpolation to construct a comprehensive archive of Australian climate data. Environ. Modell. Softw. 2001, 16, 309-330. 
20. Isbell, R.F. Australian Soil and Land Survey Handbook: The Australian Soil Classification; CSIRO Publishing: Collingwood, Australia, 1996.

21. McLaren, C. Dry Sheep Equivalents for Comparing Different Classes of Livestock; Information Notes; Department of Primary Industries: Victoria, Australia, 1997. Available online: http://www.agronomy.com.au/download/DSEratings.pdf (accessed on 1 July 2012).

22. The model is programmed using the software package Embaracadero ${ }^{\circledR}$ Delphi $^{\circledR}$ (www.embarcadero.com) and random numbers were generated using the inbuilt random number generator.

23. Dalal, R.; Wang, W.; Robertson, G.; Parton, W. Nitrous oxide emission from Australian agricultural lands and mitigation options: A review. Aust. J. Soil Res. 2003, 41, 165-195.

24. Granli, T.; Bøckman, O.C. Nitrous oxide from agriculture. Norw. J. Agr. Sci. Suppl. 1994, 12, 7-128.

25. Lawes Agricultural Trust; Genstat 12, Version 12.1 Reference Manual; Clarendon Press: London, UK, 2011.

26. Petersen, R.G.; Lucas, H.L.; Woodhouse, W.W. The distribution of excreta by freely grazing cattle and its effects on pasture fertility. I. Excretal distribution. Agron. J. 1956, 48, 440-444.

(C) 2012 by the authors; licensee MDPI, Basel, Switzerland. This article is an open access article distributed under the terms and conditions of the Creative Commons Attribution license (http://creativecommons.org/licenses/by/3.0/). 